\title{
ADDITIONS TO THE BIOECOLOGY \\ OF THE \\ NEW ENGLAND TINGIDAE AND \\ PIESMIDAE (HETEROPTERA) ${ }^{1}$
}

By Norman S. BaILey

Bradford Junior College, Bradford, Mass.

Intermittent summer collecting during the past ten years has added to my collection a considerable number of noteworthy records. These include additional stations for species previously reported from only a few localities within a particular state and for some of the less wellknown species in New England, new records for the occurrence of six species previously unreported from one or more of the New England states, and a few new host plant records.

This is the first of a series of papers now in progress which will supplement my studies of the Tingidae of New England (195 I). For ease of reference, therefore, it follows the pattern of that study in the sequence of genera and of species. (Bailey, I95 I, page 5). All collections were made by the author unless otherwise specified.

\section{Family Piesmidae \\ Piesma cinerea (Say)}

Shelton, Connecticut, August 2, I95 I Alna, Maine, August I5, I954 and August 28, 1956. Found on a weedy Amaranthus (probably retroflexus L.) on each occasion.

In 1917 Professor Parshley reported this species from ocean drift at Beach Bluff, Massachusetts, and stated, "Not found heretofore north of Rhode Island". Since then it has become well-known from this state. The records from east-central Maine extend its range appreciably. Alna is a small town adjoining $W$ iscasset in the Sheepscot River Valley about fifty miles east-northeast of Portland.

Since published records for Connecticut are few, note is made of the Shelton collection.

\section{Family Tingidae \\ Leptoypha mutica (Say)}

Windham, New Hampshire, August II, 1958.

A large collection of adults, many teneral, a few nymphs, and some exuviae was made from suppressed ash (Fraxinus) and ash suckers

\footnotetext{
${ }^{1}$ Acknowledgement is hereby gratefully made of a Sigma Xi-RESA Research Fund grant and Grant No. G5477 from the National Science Foundation, which make these studies possible.
} 
growing on a dry, rocky hillside in a stand of young mixed hardwoods. This is, I believe, the third New Hampshire record for this small lace bug.

\section{Galeatus peckhami (Ashmead)}

Katahdin Trail, Maine, August 14, I959; East Madison, New Hampshire, July 25, 1958.

Extended search was finally rewarded by these two collections from roadside asters (Aster macrophyllus L.) growing on dry, sunny banks. Though this host plant is common in northern New England, frequent search has provided only these two records. Corythucha marmorata (Uhler) is more commonly found on this aster.

\section{Gargaphia tiliae (Walsh)}

New Milford, Connecticut, August 2, I95 I Alna, Maine, August 29, I956; Carroll, Maine, August I4, I959; Petersham, Massachusetts, July I7, and I8, I95 I; Conway, New Hampshire, July 25, 1958; Eaton, New Hampshire, July 25, 1958.

In general this arboreal species may be found on its host plant Tilia. Since few records have been published, those noted will extend our knowledge of its distribution. All the collections were made from Tilia.

\section{Corythaica bellula Bueno}

Alna, Maine, August 2, 1953, August 28, 1956, and September 9, 1958; Cedar Grove, Maine, July I I, 1953; Petersham (Harvard Forest), Massachusetts, July I6 and I7, I95 I; Conway, New Hampshire, July 25, I958 (sweeping); Eaton, New Hampshire, July 25, 1958 .

Each collection was made by hand from Panicum, except in the instance noted. The Alna station was a wood road through a mature stand of Pinus strobus L. where the shade was almost constant but not intense and at a point where the road was beginning to rise at the base of a fairly sharp slope. This species was also seen, but not collected, on July I I, I953, on Panicum growing on a little used, open drive within a stone's throw of the shore at Medomak, Maine. The Cedar Grove collection was from Panicum growing on a dry bluff overlooking the Kennebec River. These are the first Maine records.

In Bradford, Massachusetts, six collections of $C$. bellula Bueno were made from Panicum by hand and two by sweeping in 1957 . Most of these were taken from an area of less than four square yards under a small red maple (Acer rubrum L.) where the Panicum was prominent and the total vegetation too sparse to cover the hard-packed 
soil. These eight collections yielded I 4 females, 4 males, and 8 nymphs. In 1958, six collections in the same area gave 6 females, ro males, and I4 nymphs. The first specimens were taken on June 9th in 1957 and the last for the season on September 7 th in 1958 . Nymphs were taken as early as June I2th and as late as August 31st. Teneral adults occurred from as early as June 22nd until as late as August I7th. These data confirm the opinion that $C$. bellula Bueno should be found throughout New England in areas ecologically suitable.

\section{Stephanitis globulifera (Matsumura)}

West Hartford, Connecticut, August 25, I958. They were abundant on Pieris japonica (Thunberg) Don used as foundation plants in front of a fairly new house in a recent development. This species first reported from North America in I950 (Bailey) is apparently well-established in Connecticut, but I have yet to collect it elsewhere.

\section{Stephanitis pyrioides (Scott)}

West Newbury (Cherry Hill), Massachusetts, August 20, 1958. Nymphs and adults were found on young stock of several deciduous azalea species and hybrids growing in a lath house.

Stephanitis rhododendri Horvath

Petersham (Harvard Forest), Massachusetts, July 17 and 18 , I95I.

The first collection was made from Kalmia latifolia L., a frequent host. The next day a few were found on $K$. angustifolia L. Although this is a very common shrub in eastern Massachusetts and Maine and, although it is on record as a host for this lace bug, this is my only collection from lambkill.

\section{Corythucha bellula Gibson}

Katahdin Trail, Maine, August 14, I959; Gorham, New Hampshire, July 21, 1958.

This is the first record of the species from New Hampshire where it was found on roadside Corylus. Note below that C. coryli O. and D. also occurs in this state. The ecology of these two species in their contact zone should be a fruitful study since both utilize the same host. The Maine collection noted is a large one of particular interest since they were all taken from Salix.

\section{Corythucha caryae Bailey}

Scituate, Rhode Island, September 23, 1958.

This interesting range extension of a species previously collected only from a relatively limited area in eastern New Hampshire and 
Massachusetts was the outstanding result of a one-day collecting trip into Rhode Island. They were found on Carya on the edge of a wooded area beside Route 14 and near the reservoir.

\section{Corythucha coryli $\mathrm{O}$. and D.}

Monroe, Connecticut, August 2, 195I ; Shelton, Connecticut, August 27, 1958; Epping, New Hampshire, September 20, 1958; Diamond Hill State Park, Rhode Island, September 23, 1958.

My collections now extend the range of this species into three more of the New England states for which there have been no published records. They were all taken from Corylus growing along the roadside.

\section{Corythucha cydoniae (Fitch)}

Newcastle, Maine, August 7, I953; Haverhill (Ward Hill), Massachusetts, July 27, 1957 and August 23, I960; Diamond Hill State Park, Rhode Island, September, 23, 1958.

This species can now be added to the faunal lists of two more New England states. Since it infests shrubs and small trees of several rosaceous genera that are widely distributed in the Northeast, the single reported occurrence north of Massachusetts suggested a wider distribution and also raised the question of limiting ecological factors. The wider range is now established but the ecological conditions controlling it surely deserve investigation. I have collected rather widely and, in a few areas, intensively in Maine with only the record cited above for this species. There it was feeding on native Crataegus in large numbers.

The single Rhode Island record, on the contrary, probably indicates lack of local interest in Tingids.

The Massachusetts records are given to report another host for C. cydoniae. Cotoneaster hupehensis Rehder and Wilson, used in a permanent shrub border in a local nursery was found to be heavily infested. About twenty yards away is a large clump of tall Amelanchier, also a part of the landscape arrangement, similarly infested. The lace bugs were breeding on both hosts.

The eighth edition of Gray's Manual of Botany (Fernald, 1950) considers Pyracantha coccinea Roemer (a previously reported host) a synonym for Cotoneaster pyracantha (L.) Spach while the 1949 revised edition of the Manual of Cultivated Plants (L.H. Bailey) maintains the distinctness of the genus Pyracantha. This leaves me with a question for the plant taxonomists to decide. If not another genus, we at least note another rosaceous species as a host for $C$. 
cydoniae which thrives on many native and cultivated forms in this plant family.

\section{Corythucha marmorata (Uhler)}

Bradford, Massachusetts, July 6, 1957; Haverhill (Ward Hill), Massachusetts, July 27, 1957.

This species ranges throughout North America. In New England it feeds exclusively on a diversity of herbaceous composites. Apparently one of America's most successful Tingids in terms both of its wide distribution and of its local abundance, it is the only species of the fifteen in the genus occurring in New England that is neither arboreal nor thamnophilous. Its catholic preference for ubiquitous composites undoubtedly accounts in no small measure for its success.

Consequently, it was not surprising to find it thriving on two species previously unlisted. The Bradford observation was made on Rudbeckia serotina Nuttall, the common Black-eyed Susan or Yellow Daisy. On Ward Hill they were found on the cultivated Globe Thistle, Echinops sphaerocephalus L.

\section{Corythucha mollicula O. and D.}

Monroe, Connecticut, August 2, I95I; Newtown, Connecticut, August 2, 195 I ; Aurora, Maine (collected by Dr. A. G. Humes), July 13, I950; Rockport, Maine, September io, I958; Sheepscot, Maine, August 6, I953; Petersham (Harvard Forest), Massachusetts, July I8, I95I; Diamond Hill State Park, Rhode Island, September 23, 1958 .

Probably again because of lack of collector interest, few records have been published for this species. Therefore, these, all from Salix, are cited.

\section{Corythucha pruni O. and D.}

Brookfield, Connecticut, August 2, I95I; Monroe, Connecticut, August 2, I95 I Shelton, Connecticut, August 27, 1958; Mattatuck, Connecticut, August 28, 1958; Alna, Maine, August 28, 1956 and September 9, 1958; Cedar Grove, Maine, September 15, 1957 and May 28, 1959; Dresden, Maine, June 22, I957; Mexico, Maine (collected by Mr. J. J. B. Anderson), September 7, I959; Newcastle, Maine, August 7, 1953; South Bristol, Maine, August 24, 1956; South Cushing, Maine, September IO, 1958; Epping, New Hampshire, September 20, 1958; Diamond Hill State Park, Rhode Island, September 23, 1958; Waterman, Rhode Island, September 23, 1958. 
The Maine records cited establish the frequent occurrence of this species in the central coastal region and in other parts of that state. Another locality is added to the few published New Hampshire records. Rhode Island and Connecticut stations are given for the first time.

Of particular interest is the fact that the specimens from the two southernmost New England states suggest that typical Corythucha pruni $\mathrm{O}$. and $\mathrm{D}$. and typical $C$. associata $\mathrm{O}$. and $\mathrm{D}$. may represent extreme forms which have differentiated in the recent past from a common population. The latter has not yet been collected in Massachusetts nor further north. Until now, C. pruni had not been reported from southern New England. Both species restrict their feeding entirely to Prunus serotina Ehrhart. The collections noted above were all from this host. Two collections made in Connecticut in I95 I aroused my curiosity. In both, specimens of the two species were found on the same host plants. On recent critical examination of this material, I found that the Brookfield collections consisted of 26 spicimens. Three of these were, on basis of hood size and form, definitely $C$. pruni (2 males and a female), 22 were $C$. associata, and one was questionably $C$. associata because the top of the hood was missing. Among the associata forms there was some variation in the height and width of the hood. The Monroe collection made the same day consisted of 38 that were surely $C$. pruni and a single female of $C$. associata. More recently a collection from Mattatuck produced 9 males of $C$. pruni and one female of $C$. associata. In Shelton one C. pruni male was found on a Prunus and another host plant in that town yielded 100 adults of $C$. associata.

Close study of these two species in Connecticut should answer some important questions. Except for the marked differences in their hood forms and, more significantly, the claspers of the males, they are very similar. In size and coloration they are almost identical. Frequent collections in several localities in this contact zone throughout one or two seasons would give valuable population information and specimens for careful comparison of structural details.

As previously mentioned, a similar situation involving the species C. bellula Gibson and C. coryli O. and D. whose primary host is Corylus may exist from central Maine and New Hampshire westward. Again we find two species of similar size with minor morphological distinctions. Similarly intriguing is the relationship between our two New England species whose host is commonly Alnus. Here, however, there are greater differences in size in addition to the 
differences in structural details between the two and, consequently, their kinship is possibly more remote.

\section{Corythucha ulmi O. and D.}

Brookfield, Connecticut, August 2, I95I. Published Connecticut records are few. In my experience, this species is only rarely found even where elms are common.

\section{Literature Cited}

Bailey, L. H., 1949. Manual of Cultivated Plants. Macmillan, New York. BaIley, Norman S., 1950. An Asiatic Tingid New to North America. Psyche, $57: 143-145$.

1951. The Tingoidea of New England and Their Biology. Entomoíogica Americana, 31 (n.s.) :1-140.

Fernald, M. L., 1950. Gray's Manual of Botany (Eighth Edition). American Book Company, Boston.

Parshley, H. M., 1917 a. Insects in Ocean Drift. Canadian Entomologist, 49 (2) :45-48.

1917 b. Fauna of New England, 14. List of the Hemiptera-Heteroptera. Boston Society of Natural History, Occasional Papers, $7: 1-125$. 

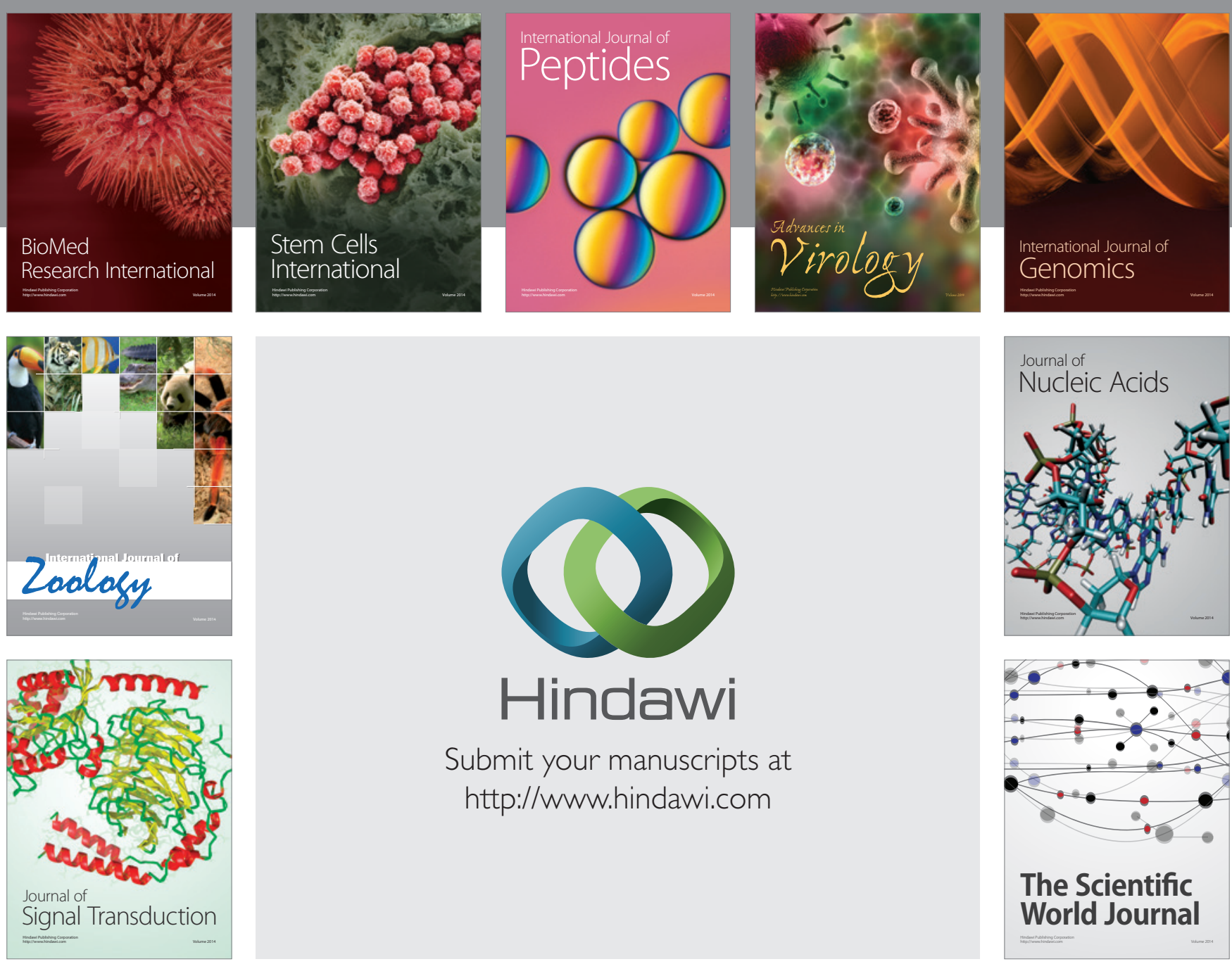

Submit your manuscripts at

http://www.hindawi.com
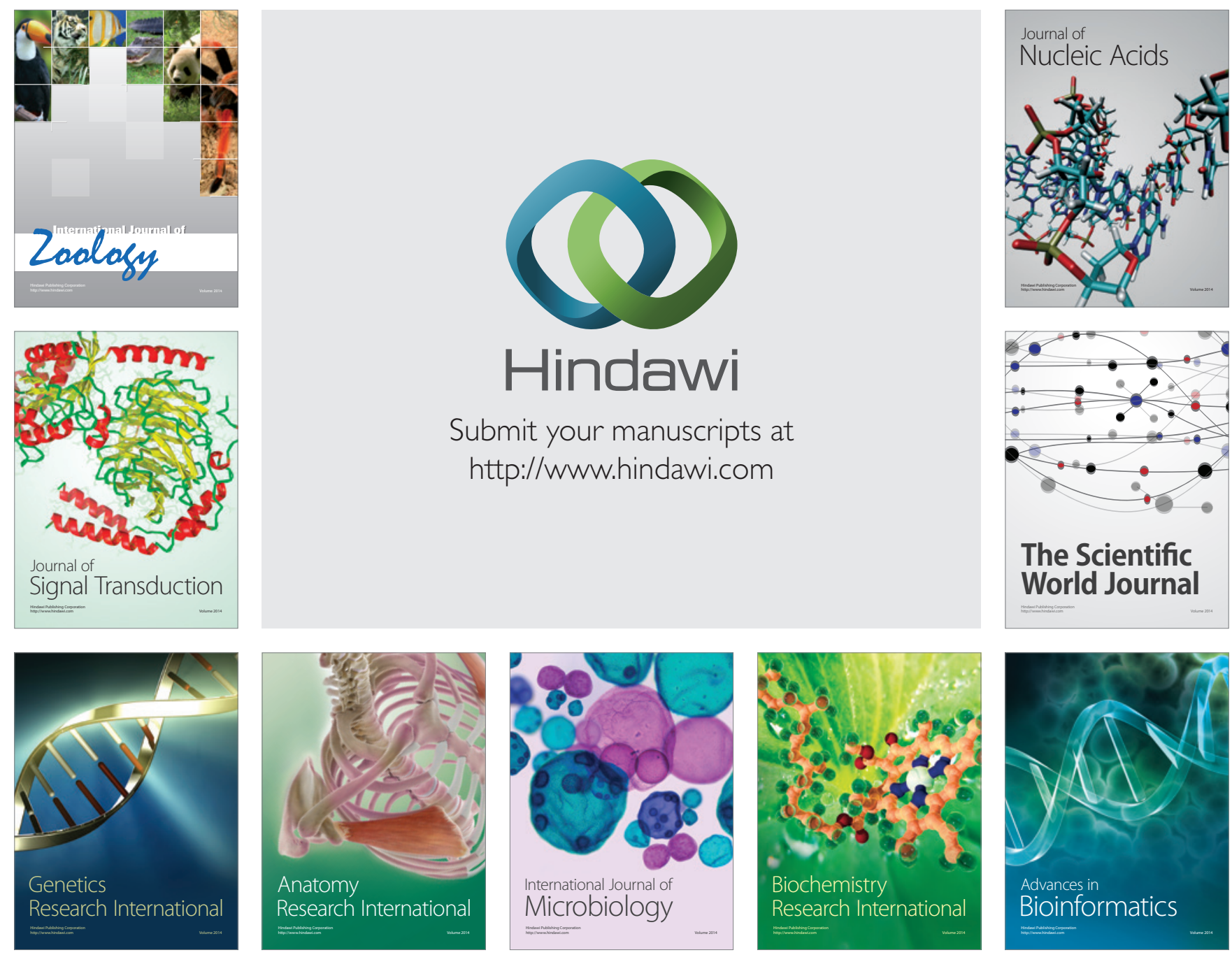

The Scientific World Journal
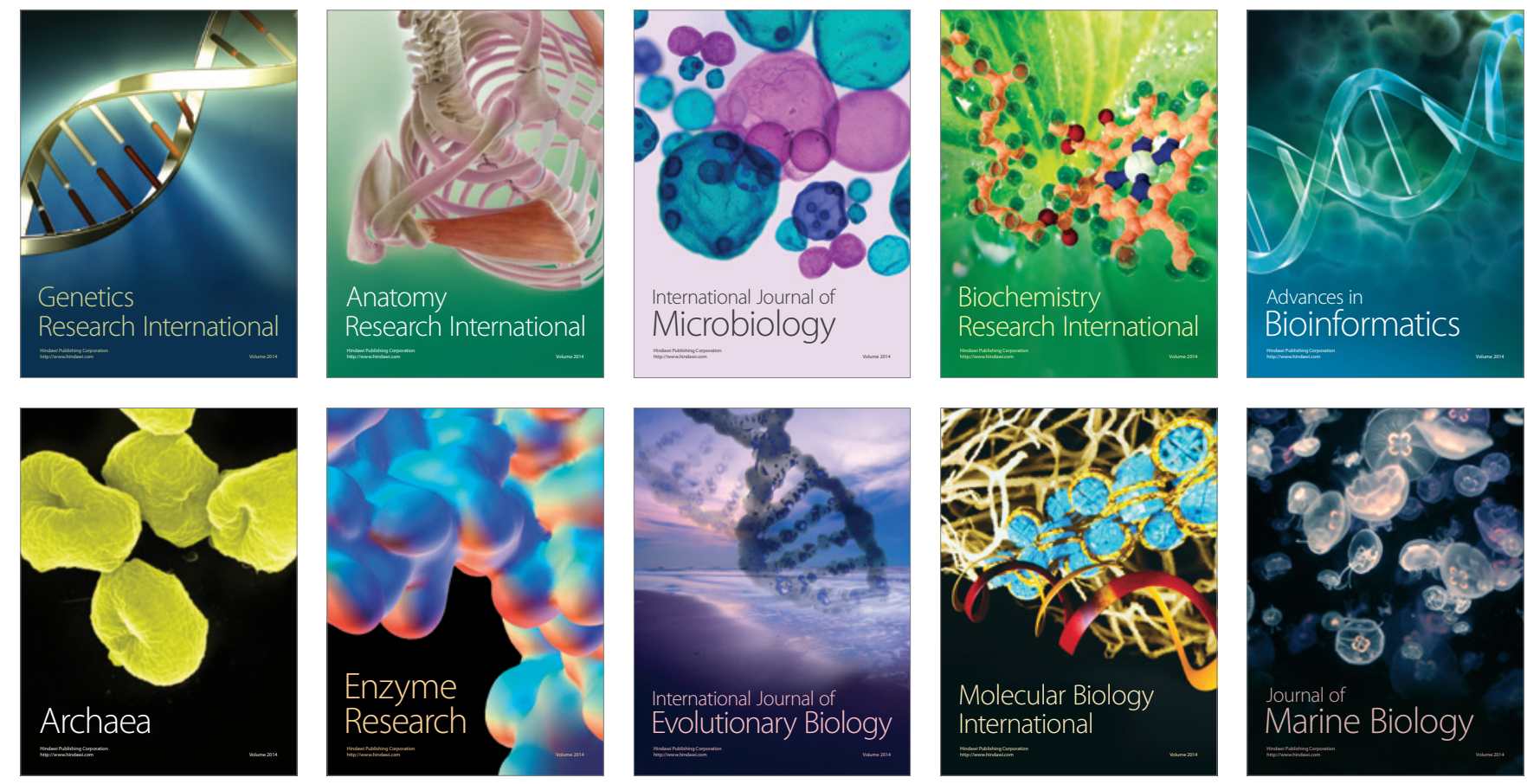